\title{
Hypoploidy defines patients with poor prognosis in breast cancer
}

\author{
ELISABET CHAVEZ-URIBE ${ }^{1}$, JOSÉ CAMESELLE-TEIJEIRO ${ }^{1}$, JUAN E. VIÑUELA ${ }^{2}$, CARMEN CASTRO-PIÑEIRO $^{3}$, \\ FRANCISCO GUDE ${ }^{4}$, JERÓNIMO FORTEZA ${ }^{1}$ and JOSÉ LUIS PUENTE-DOMÍNGUEZ ${ }^{3}$ \\ ${ }^{1}$ Departments of Pathology, ${ }^{2}$ Immunology, and ${ }^{3}$ Surgery, and ${ }^{4}$ Clinical Epidemiology Unit, \\ Hospital Clínico Universitario, University of Santiago de Compostela, Santiago de Compostela, Spain
}

Received December 4, 2006; Accepted February 9, 2007

\begin{abstract}
The clinicopathological features currently used in breast cancer prognosis often fail to characterize the clinical heterogeneity of the disease accurately. Our study is aimed to investigate the predictive value of DNA flow cytometry in breast cancer. Previously untreated breast carcinoma samples (584) were snap frozen for flow-cytometry. Tumors were classified into three DNA index (DI) categories: i) tumors showing a DI =0.96-1.15 (diploid and near-diploid); ii) tumors with a DI $\geq 1.16$ (hyperdiploid, tetraploid, multiploid and/or those with more than one diploid population); and iii) tumors with a DI $\leq 0.95$ (hypoploid). The 5- and 10-year cumulative survival rates \pm SE for Group I $(n=191)$ were $98 \pm 1 \%$ and $98 \pm 1 \%$. For Group II $(n=361)$ these rates were $77 \pm 2 \%$ at 5 years and $63 \pm 5 \%$ at 10 years. In Group III $(n=32)$ the rate at 5 years was $23 \pm 8 \%$, with no patients alive at 10 years $(\mathrm{p}<0.0001)$. In univariate analysis, tumor size, node status, grade, karyometry, S-phase fraction, MIB-1 index, and estrogen receptors retained prognostic significance; in multivariate analysis, only DI $\leq 0.95$ (hypoploid) was retained as an independent prognostic factor for overall survival. Our data strongly support that DNA hypoploid has a strong, independent prognostic value for predicting the short-term clinical outcome of breast carcinoma patients.
\end{abstract}

\section{Introduction}

Cancer of the breast is one of the most common human neoplasms, accounting for approximately one quarter of all cancers in females (1). Breast carcinomas exhibit a wide range of morphological phenotypes and specific histopathological types have particular prognostic or clinical characteristics $(1,2)$. The clinicopathological features currently used in breast cancer prognosis often fail to characterize the clinical heterogeneity

Correspondence to: Dr Elisabet Chavez-Uribe, Department of Anatomic Pathology, Hospital Clínico Universitario, 15706 Santiago de Compostela, Spain

E-mail: apjocame@usc.es

Key words: flow cytometry, breast carcinoma, DNA hypoploid, prognostic factor, invasive ductal carcinoma of the disease accurately, particularly with respect to predicting tumor behavior in the individual case $(1,2)$. In recent years, therefore, in several areas, including analytical cytology, immunocytochemistry, and molecular biology, attempts have been made to identify features that could be clinically useful in assessing prognosis (3-7).

The predictive role of DNA flow cytometry in patients with breast carcinoma has been investigated in many studies (8-12). In some it was concluded that DNA ploidy and S-phase fraction (SPF) were useful in predicting clinical outcome, with SPF, particularly, often claimed as having independent prognostic value (9-13). Other studies, however, have shown that flow cytometry data analysis provides no additional prognostic information (14). It is generally accepted that most of the controversy over these results stems from the different methods and criteria used in the various studies (15). Apart from intratumor heterogeneity $(15,16)$, confounding factors include patient selection bias, differences in treatment, insufficient numbers of patients, differences in the type of sample used (fresh versus paraffin embedded), the tissue processing procedures, and the criteria used for interpreting the histograms $(14,15,17)$.

Our aim was to investigate the predictive value of DNA flow cytometry in breast cancer, applying well-recognized software for DNA histogram interpretation. We evaluate the correlation between DNA content (ploidy), S-phase fraction and other established clinicopathological prognostic factors in a series of carcinomas using fresh/frozen material. We analyzed the impact of this information on disease-free survival in the short-term and on overall survival after primary surgical treatment to identify a group of patients who might have a significantly worse prognosis.

\section{Materials and methods}

Clinicopathological data. The study involved 584 women with operable breast cancer diagnosed and treated between April 1991 and December 2000 at Clinical University Hospital (Santiago de Compostela, Spain). These patients were treated in our institution according to standard protocols. The mean age of the patients was 59 years (range, 25-85 years). Median follow-up time was 102 months (range, 48-156 months). Informed consent was obtained for this study, which was conducted according to the Spanish law including adherence to the Helsinki Principles of 1975, as revised in 1983. 
Table I. Clinicopathological, karyometric, and immunohistochemical characteristics of a series of primary breast carcinomas in relation to ploidy (univariate analysis).

\begin{tabular}{|c|c|c|c|c|}
\hline $\begin{array}{l}\text { Groups } \\
\text { Ploidy } \\
\text { Number of patients }\end{array}$ & $\begin{array}{l}\text { Group I } \\
\text { Diploid and near-diploid } \\
n=191\end{array}$ & $\begin{array}{l}\text { Group II } \\
\text { Aneuploid }^{\mathrm{a}} \\
\mathrm{n}=361\end{array}$ & $\begin{array}{l}\text { Group III } \\
\text { Hypoploid } \\
n=32\end{array}$ & $\mathrm{p}$ value \\
\hline Age (years) & $60.0 \pm 12.8$ & $57.7 \pm 14.0$ & $58.1 \pm 13.4$ & $\mathrm{NS}^{\mathrm{b}}$ \\
\hline $\begin{array}{l}\text { Hormonal status } \\
\text { Pre-menopausal } \\
\text { Peri-menopausal } \\
\text { Menopausal }\end{array}$ & $\begin{array}{l}38(19.9 \%) \\
25(13.1 \%) \\
128(67 \%)\end{array}$ & $\begin{aligned} 110 & (30.5 \%) \\
32 & (8.9 \%) \\
219 & (60.7 \%)\end{aligned}$ & $\begin{array}{c}9(28.1 \%) \\
2(6.3 \%) \\
21(65.6 \%)\end{array}$ & NS \\
\hline $\mathrm{FHBC}^{\mathrm{c}}$ & $26(13.8 \%)$ & $65(18.1 \%)$ & $5(15.6 \%)$ & NS \\
\hline Tumor size (cm) & $2.7 \pm 1.5$ & $3.5 \pm 2.1$ & $6.6 \pm 5.9$ & 0.000 \\
\hline $\begin{array}{l}\text { Histological type } \\
\text { IDC }^{d} \\
\text { DCIS }^{\mathrm{e}} \\
\mathrm{ILC}^{\mathrm{f}} \\
\mathrm{IMC}^{\mathrm{g}} \\
\text { Other }\end{array}$ & $\begin{array}{c}152(79.6 \%) \\
11(5.8 \%) \\
15(7.9 \%) \\
5(2.6 \%) \\
8(4.2 \%)\end{array}$ & $\begin{array}{c}309(85.6 \%) \\
6(1.7 \%) \\
30(8.3 \%) \\
11(3 \%) \\
5(1.4 \%)\end{array}$ & $\begin{array}{c}27(84.4 \%) \\
0 \\
5(8.6 \%) \\
0 \\
0\end{array}$ & NS \\
\hline Axillary lymph node metastases & $69(37.9 \%)$ & $196(56.2 \%)$ & $25(78.1 \%)$ & 0.000 \\
\hline $\begin{array}{l}\text { Microscopic grade } \\
\text { Grade I } \\
\text { Grade II } \\
\text { Grade III }\end{array}$ & $\begin{array}{l}45(29.6 \%) \\
89(58.6 \%) \\
18(11.8 \%)\end{array}$ & $\begin{array}{r}59(19.2 \%) \\
170(55.4 \%) \\
78(25.4 \%)\end{array}$ & $\begin{array}{r}3(11.5 \%) \\
15(57.7 \%) \\
8(30.8 \%)\end{array}$ & 0.003 \\
\hline Nuclear area & $77( \pm 13)$ & $114( \pm 49)$ & $91( \pm 37)$ & 0.000 \\
\hline Perimeter & $61( \pm 5)$ & $73( \pm 15)$ & $65( \pm 12)$ & 0.000 \\
\hline Spherical & $65( \pm 11)$ & $56( \pm 15)$ & $60( \pm 12)$ & 0.000 \\
\hline Oval & $29( \pm 7)$ & $30( \pm 7)$ & $29( \pm 8)$ & NS \\
\hline Cylindrical & $5( \pm 8)$ & $12( \pm 13)$ & $9( \pm 7)$ & 0.000 \\
\hline Percentage S-phase (\%) & $5.5 \pm 3.5$ & $8.5 \pm 5.9$ & $10.1 \pm 6.3$ & 0.000 \\
\hline $\begin{array}{l}\text { S-phase fraction } \\
\text { Low } \\
\text { Moderate } \\
\text { High }\end{array}$ & $\begin{array}{c}115(60.2 \%) \\
57(29.8 \%) \\
19(9.9 \%)\end{array}$ & $\begin{array}{l}120(33.2 \%) \\
136(37.7 \%) \\
105(29.1 \%)\end{array}$ & $\begin{array}{r}5(15.6 \%) \\
15(46.9 \%) \\
12(37.5 \%)\end{array}$ & 0.000 \\
\hline $\begin{array}{l}\text { MIB-1 } \\
\text { Low } \\
\text { Moderate } \\
\text { High }\end{array}$ & $\begin{array}{l}51(40.2 \%) \\
52(40.9 \%) \\
24(18.9 \%)\end{array}$ & $\begin{array}{r}63(24.6 \%) \\
107(41.8 \%) \\
86(36.6 \%)\end{array}$ & $\begin{array}{l}5(26.3 \%) \\
7(36.8 \%) \\
7(36.8 \%)\end{array}$ & 0.008 \\
\hline $\begin{array}{l}\text { Estrogen receptors } \\
\text { Negative } \\
\text { Positive }\end{array}$ & $\begin{array}{r}26(16.0 \%) \\
136(84.0 \%)\end{array}$ & $\begin{array}{r}93(28.2 \%) \\
237(71.8 \%)\end{array}$ & $\begin{array}{r}8(26.7 \%) \\
22(73.3 \%)\end{array}$ & 0.012 \\
\hline $\begin{array}{l}\text { Progesterone receptors } \\
\text { Negative } \\
\text { Positive }\end{array}$ & $\begin{array}{l}55(35.9 \%) \\
98(64.1 \%)\end{array}$ & $\begin{array}{l}124(40.9 \%) \\
179(59.1 \%)\end{array}$ & $\begin{array}{r}11(55.0 \%) \\
9(45.0 \%)\end{array}$ & 0.220 \\
\hline $\begin{array}{l}\text { P53 } \\
\text { Negative } \\
\text { Positive }\end{array}$ & $\begin{array}{l}81(62.8 \%) \\
48(37.2 \%)\end{array}$ & $\begin{array}{l}163(61.3 \%) \\
103(38.7 \%)\end{array}$ & $\begin{array}{r}11(55.0 \%) \\
9(45.0 \%)\end{array}$ & 0.798 \\
\hline
\end{tabular}

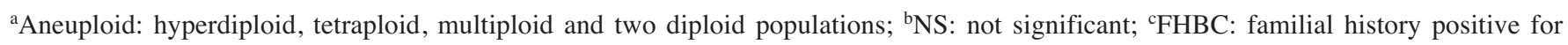
breast cancer; ${ }^{\mathrm{d} I D C}$ : invasive ductal carcinoma; ${ }^{\mathrm{e} D C I S}$ : ductal carcinoma in situ; ${ }^{\mathrm{f} I L C}$ : invasive lobular carcinoma; ${ }^{\mathrm{g}} \mathrm{IMC}$ : invasive medullary carcinoma. Quantitative data are expressed as mean \pm SD. 
In every tumor, 4- $\mu \mathrm{m}$ histological sections were cut and stained with hematoxylin and eosin for histopathological examination according to the criteria of the World Health Organization (1). Histological grading was evaluated using the Nottingham modification of the Bloom-Richardson system (18). All relevant clinicopathological characteristics are summarized in Table I. Immunohistochemical analysis on paraffin-embedded material was performed using a universal second antibody kit that used a peroxidase-conjugated labeleddextran polymer (EnVision ${ }^{\circledR}$, Peroxidase/DAB; Dako, Glostrup, Denmark), with antibodies for estrogen receptor (clone 6F11, dilution 1:10, microwave oven; Novocastra, Newcastle-uponTyne, UK), progesterone receptor (clone PgR 636, dilution 1:50, water bath; Dako), MIB-1 (clone Ki-67, dilution 1:100, water bath; Dako), and p53 (clone DO7, dilution 1:20, water bath; Novocastra). Negative and positive controls were concurrently run for all antibodies with satisfactory results. Cells were considered immunopositive when diffuse or dot-like nuclear staining was observed regardless of the intensity of the staining; only nuclear immunoreactivity was considered specific. The number of positive cells was counted by two different observers independently (EC-U and JC-T). Whenever necessary, a consensus was reached using a double-headed microscope. In accordance with the percentage of positive cells for MIB-1, the proliferation index was considered low $(\leq 17 \%)$, moderate $(18-34 \%)$, and high $(\geq 35 \%)$.

Flow cytometry. Flow cytometry analysis was performed on fresh material from specimens obtained at the time of surgery as previously reported (19). Tissue samples were selected by a pathologist and were stored at $-80^{\circ} \mathrm{C}$. On average the tissue samples examined measured $0.5 \times 0.4 \times 0.2 \mathrm{~cm}$. The frozen tissue samples were disaggregated in buffer solution (FACSFlow, Becton Dickinson, Franklin Lakes, NJ, USA). The resulting cell suspension was passed through a nylon filter with $30-\mu \mathrm{m}$ meshes and centrifuged for $10 \mathrm{~min}$ at $1500 \mathrm{rpm}$. The supernatant was aspirated and discarded, and the pellet was resuspended in buffer solution (FACSFlow, Becton Dickinson) $1 \mathrm{ml}$ and passed through $30-\mu \mathrm{m}$ meshes. The concentration of cells in the resulting suspension was estimated by microscopic examination of a $20-\mu 1$ sample stained with trypan blue; the bulk of the suspension was brought to a concentration of $1 \times 10^{6}$ cells $/ \mathrm{ml}$, and a $1-\mathrm{ml}$ sample was taken and treated with $100 \mu 1$ of $1 \mathrm{mg} / \mathrm{ml}$ RNA-ase (Sigma, R-5503, St. Louis, MO, USA) and $50 \mu 1$ of propidium iodide $400 \mu \mathrm{g} / \mathrm{ml}$ (Sigma, P-4170) as a fluorescent marker. After $45 \mathrm{~min}$ in the dark at room temperature, the sample was examined by FACSCalibur Flow Cytometer ${ }^{\circledR}$ (Becton Dickinson).

DNA histograms were analyzed by the cytometer software (ModFit LT $^{\circledR}$ for Mac V3.0, Topsham, ME), which automatically suppressed background caused by cell debris and calculated the percentages of $\mathrm{G}_{0} / \mathrm{G}_{1^{-}}, \mathrm{G}_{2} \mathrm{M}$ - and S-phase cells in each cell population. Patients with samples whose DNA histogram had a diploid $\mathrm{G}_{0} / \mathrm{G}_{1}$ peak with a coefficient of variation $>5 \%$ were excluded from the study (this occurred exclusively at the start of the study, and is attributed to lack of experience for preparing the samples). The tumor samples were classified into three categories in relation to DNA index (DI): Group I diploid (DI =0.96-1.05), and near-diploid (DI =1.06-1.15); Group II hyperdiploid (DI =1.16-1.75), tetraploid
(DI =1.76-2.10), multiploid (DI = two or more aneuploid peaks), and two diploid populations; and Group III hypoploid (DI $\leq 0.95$ ).

Karyometry. Karyometry was carried out at a magnification of $\mathrm{x} 400$ using a light microscope with an eyepiece equipped with a micrometer grid. Details of procedures have been described in a previous publication (19). For each sample, the maximum $\left(\mathrm{D}_{\max }\right)$ and minimum $\left(\mathrm{D}_{\min }\right)$ diameters of the nuclei of 100 cells were measured and their cytonuclear areas were calculated as $D_{\max } \times D_{\min } \times(\pi / 4)$. On the basis of their mean cytonuclear area, samples were classified as normokaryotic (area $<100 \mu \mathrm{m}^{2}$ ), magnokaryotic (area 100-140 $\mu \mathrm{m}^{2}$ ), or megalokaryotic $\left(\operatorname{area}>140 \mu \mathrm{m}^{2}\right)$. The perimeter and shape of these tumor cells were also evaluated.

Database and statistics. All statistical analyses were performed with the Statistical Package for the Social Sciences (version 10; SPSS ${ }^{\circledR}$ Inc., Chicago, IL). Curves for DFS were calculated according to the Kaplan and Meier method, and differences between curves were assessed with the log-rank test for censored data on survival. Cox's regression model was used to evaluate the predictive power of prognostic factors in the multivariate analysis. Continuous variables are expressed as mean $\pm \mathrm{SD}$.

\section{Results}

Clinicopathological data. The clinicopathological data are summarized in Table I. After histological re-evaluation the study included 584 invasive carcinomas: 488 (88.1\%) ductal type, 50 (9\%) lobular type, 16 (2.8\%) medullary type, and 13 invasive carcinomas of a miscellanous group that included 2 $(0.36 \%)$ tubular carcinomas, 7 (1.3\%) mucinous carcinomas and $4(0.72 \%)$ papillary carcinomas, as well as 17 in situ ductal carcinomas.

DNA analysis. Table I shows the correlations between the three groups classified according to the DNA index and the different tumor features. Of the 584 breast tumors analyzed by flow cytometry, 191 were in Group I [107 (18.3\%) diploid and $84(14.4 \%)$ near-diploid], 361 in Group II [134 (22.9\%) hyperdiploid, 124 tetraploid, $48(8.2 \%)$ multiploid and 55 $(9.4 \%)$ with two diploid populations], and 32 (5.5\%) in Group III (hypoploid) (Fig. 1). A greater size (on average) was found in the group of hypoploid tumors $(6.6 \pm 5.9 \mathrm{~cm})$ in contrast with Groups I $(2.7 \pm 1.5 \mathrm{~cm})$ and II $(3.5 \pm 2.1 \mathrm{~cm})$. In Group III (hypoploid) all 32 cases were invasive carcinomas $(84.4 \%$ invasive ductal type and $8.6 \%$ invasive lobular type), without in situ carcinomas in this group. A significantly higher number of patients $(78.1 \%)$ with axillary lymph node metastases were also found in the hypoploid group $(\mathrm{p}<0.0001)$.

Overall, more than half of the tumors were histologically classified as grade II; however, the hypoploid group included a higher percentage of grade III tumors, and there were only 3 grade I neoplasms. Regarding karyometric parameters, the nuclear area and the perimeter were higher in the aneuploid group $(\mathrm{p}<0.0001)$.

In relation to proliferative activity, the fraction (and percentage) of S phase as well as the percentage of immuno- 

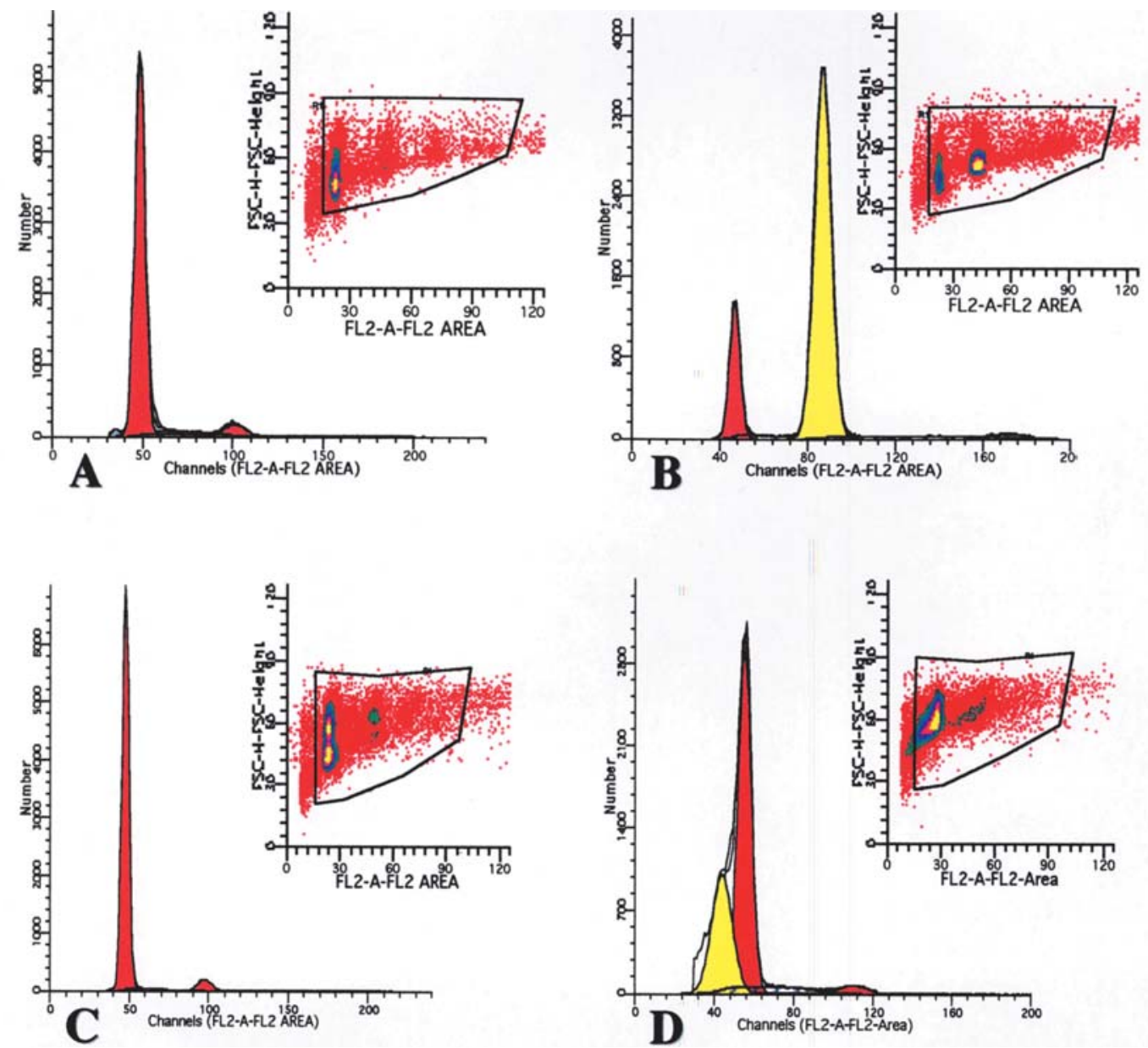

Figure 1. Flow cytometric DNA. A, diploid histogram (Group I); B, tetraploid histogram (Group II); C, two diploid population histogram (Group II); and D, hypoploid histogram (Group III).

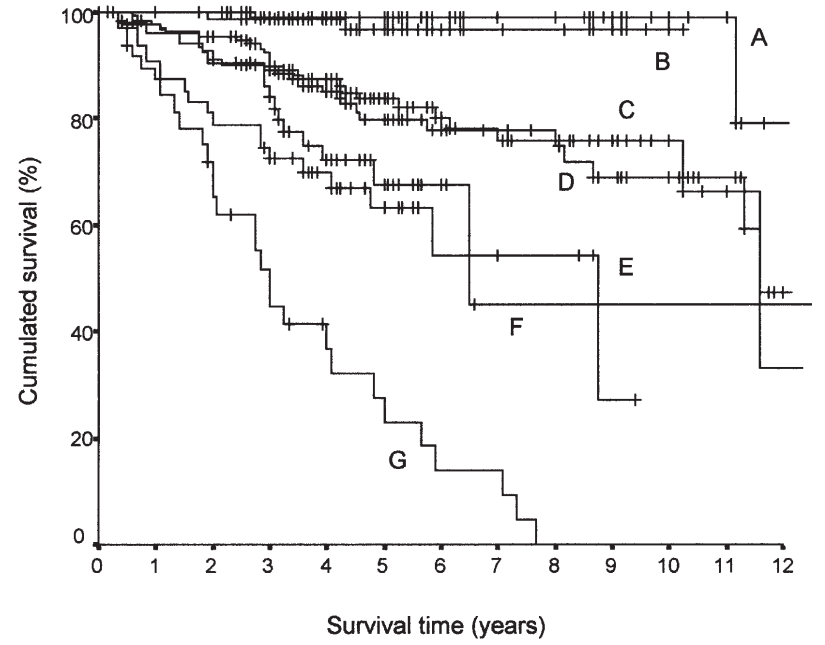

Figure 2. Analysis of disease-free survival according to ploidy (Kaplan and Meier plots). A, diploid; B, near-diploid; C, tetraploid; D, hyperdiploid; E, multiploid; F, two diploid populations; and G, hypoploid.

expression of MIB-1 were higher in the hypoploid group $(\mathrm{p}<0.0001)$. An association between estrogen receptor expression and Group I was also found $(\mathrm{p}=0.01)$.

Survival analysis. Median follow-up time was 102 months (range, 48-156 months). The 5- and 10-year cumulative

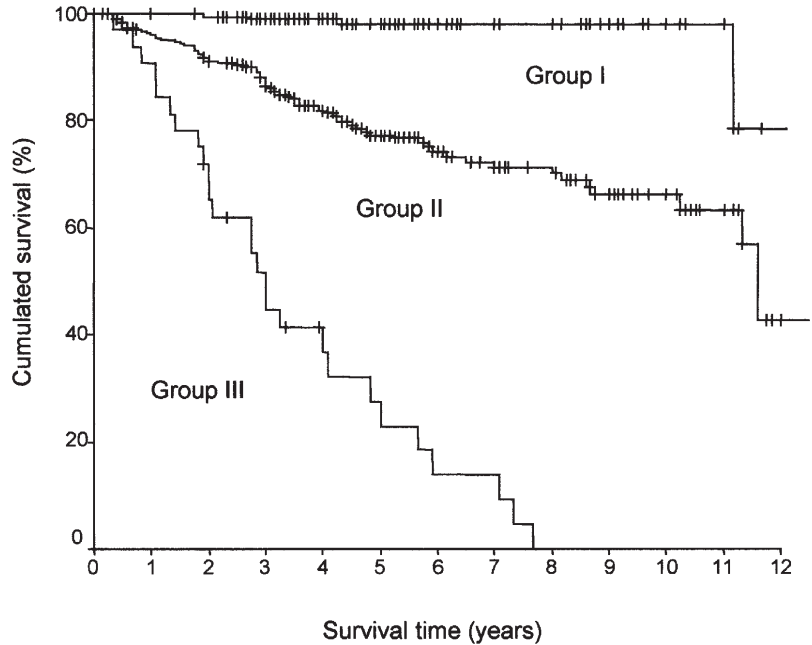

Figure 3. Analysis of disease-free survival according to ploidy (Kaplan and Meier plots). Group I, diploid and near-diploid; Group II, aneuploid; and Group III, hypoploid.

survival rate \pm SE for Group I $(n=191)$ was $98 \pm 1 \%$ and $98 \pm 1 \%$ respectively. For Group II $(\mathrm{n}=361)$ the cumulative survival rate was $77 \pm 2 \%$ at 5 years and $63 \pm 5 \%$ at 10 years. In Group III $(n=32)$ a cumulative survival rate at 5 years of $23 \pm 8 \%$ was found with no patients alive at 10 years $(\mathrm{p}<0.0001)$ (Figs. 2 and 3). In univariate analysis, tumor size, node status, grade, 
karyometry, S-phase fraction, MIB-1 index, and estrogen receptors retained prognostic significance, whereas in the multivariate analysis, only DI $\leq 0.95$ (hypoploid) was retained as having independent prognostic significance in relation with overall survival.

\section{Discussion}

Prognosis of breast carcinoma is related to a large variety of clinical and pathological factors $(1,2)$. The overall issue of DNA index, or ploidy, as a marker for breast cancer has been controversial for a number of years. The aims of the present study were to ascertain the prognostic impact of ploidy in breast cancer and its relation to other classic clinicopathological prognosis factors.

The recommendations of the 1993 DNA Cytometry Consensus Conference (14) have appeared to be insufficient to ensure interlaboratory reproducibility. For these reasons Duigou et al (17) and others $(20,21)$ established more standardized procedures using frozen tissue samples to minimize fluctuations in measurements when using different cytometers and software. However in a more recent consensus under the auspices of the College of American Pathologists published in 2000, a multidisciplinary group of clinicians, pathologists, and statisticians considered that DNA ploidy analysis is a factor which has still not been studied sufficiently to demonstrate its prognostic value (3). Although the same authors concluded that neither DNA index nor DNA ploidy status achieves independent prognostic significance, they considered that distinguishing hypoploid tumors from near-diploid and hyperploid tumors correlates with different clinical outcomes (3). Michels et al (9) and Wenger and Clark (22), however, after reviewing literature restricted to papers involving more than 100 patients and using fresh or frozen samples, demonstrated a relation between DNA ploidy and prognosis in 17 studies, in half of them after multivariate analysis.

The use of fresh/frozen tumor tissue in our study minimized the background, aggregates and debris, made fixation unnecessary, and resulted in sufficient histogram data. We showed that DNA hypoploid has a strong, independent prognostic value for predicting the short-term clinical outcome of breast carcinoma patients. In the study of Fernö et al (23), hypoploid aneuploidy was associated with the worst clinical outcome of all types of aneuploidy, even after adjustment of other prognostic factors. In the literature, the incidence of hypoploid tumors ranged from 0 to $7 \%$, with most studies agreeing on a value between 2 and $2.5 \%(9,22-29)$. We found 32 (5.5\%) cases of hypoploid tumors, which is within the range of previously reported values. In agreement with our results, all other studies $(22,25-28)$ focusing on hypoploid tumors, with the exception of that of Michel et al (9), found that these tumors were correlated with a worse prognosis. In the study of Michel et al (9) the tumors with one hypoploid peak were found to have a better prognosis than diploid tumors; however, tumors that were both hypoploid and multiploid had a significantly worse prognosis.

In our series, the 584 frozen tissue samples were classified in three categories in relation to DNA index. This classification in three groups was based on a previous evaluation of the relationship between survival and DNA content. We observed that the diploid and near-diploid group showed a very good prognosis in clear contrast to the hypoploid tumor group in which there were no survivors after 10 years. The tetraploid, hyperdiploid, multiploid and two diploid population tumor group had an intermediate outcome. Interestingly, to the best of our knowledge, the category of tumors with two diploid populations had not previously been reported in the literature. The two diploid populations are detected when the sample passes through the cytometer but they are represented in the histogram as a single diploid peak. The consideration of these tumors as aneuploid as opposed to bona fide single diploid tumors was supported by survival analysis. In addition, we cannot exclude the possibility that these two diploid population tumors with an intermediate prognosis could include neardiploid or hypoploid cell populations that are not detected by the software of the flow cytometer.

In the present study, DNA hypoploid was shown to be the most important and independently significant prognostic factor in relation to overall survival. The group of hypoploid tumors also correlated with greater tumor size, axillary lymph node metastases, higher histological grade and higher proliferative activity (fraction of S phase and/or percentage of MIB-1 immunoexpression), factors which are all well recognized as associated with a worse prognosis (2-4). A rough correlation was found in our study between fraction of $S$ phase and percentage of MIB-1.

In conclusion, when using generalized guidelines for flow cytometric DNA measurements $(3,15,17,21)$, and classifying tumors in the three DNA index categories that we have designated in this paper, DNA ploidy is a good tool for establishing a prognosis for breast cancer. DNA hypoploid, more specifically, has strong, independent prognostic value for predicting the short-term clinical outcome of breast carcinoma patients. Loss of chromosome 4 and amplification of the cyclin D1 oncogene were defined as characteristic aberrations in hypoploid tumors (30), indicating that histologically indistinguishable ductal invasive breast carcinomas consist of several distinct entities (such as hypoploid tumors) that can be defined by modern molecular techniques (comparative genomic hybridization and fluorescence in situ hybridization) $(30,31)$. Our paper strongly supports the usefulness of DNA flow cytometry as a technique that is faster and simpler than other more recently developed molecular techniques in the selection of patients in clinical oncology.

\section{Acknowledgments}

Supported by a research grant sponsored by Fundación MMA (Medical Research), Madrid, Spain. Dedicated to the memory of Professor José Luis Puente-Dominguez, who passed away shortly after this manuscript had been completed.

\section{References}

1. Ellis IO, Schnitt SJ, Sastre-Garau X, et al: Invasive breast carcinoma. In: World Health Organization Classification of Tumours. Pathology and Genetics of Tumours of the Breast and Female Genital Organs. Tavassoli FA and Devilee P (eds). IARC Press, Lyon, pp9-110, 2003.

2. Rosai J: Breast. In: Rosai and Ackerman's Surgical Pathology. Rosai J (ed). Vol. 2, 9th edition. Mosby, St. Louis, pp1763-1876, 2004. 
3. Fitzgibbons PL, Page DL, Weaver D, et al: Prognostic factors in breast cancer. College of American Pathologists Consensus Statement 1999. Arch Pathol Lab Med 124: 966-978, 2000.

4. Ross JS, Linette GP, Stec J, et al: Breast cancer biomarkers and molecular medicine. Expert Rev Mol Diagn 3: 573-585, 2003.

5. Mehra R, Varambally S, Ding L, et al: Identification of GATA3 as a breast cancer prognostic marker by global gene expression meta-analysis. Cancer Res 65: 11259-11264, 2005.

6. Abdulkader I, Sanchez L, Cameselle-Teijeiro J, et al: Cellcycle-associated markers and clinical outcome in human epithelial cancers: a tissue microarray study. Oncol Rep 14: 1527-1531, 2005.

7. Madan R, Smolkin MB, Cocker R, Fayyad R and Oktay MH: Focal adhesion proteins as markers of malignant transformation and prognostic indicators in breast carcinoma. Hum Pathol 37: 9-15, 2006.

8. Ross JS, Linette GP, Stec J, Ross MS, Anwar S and Boguniewicz A: DNA ploidy and cell cycle analysis in breast cancer. Am J Clin Pathol 120 (suppl): S72-S84, 2003.

9. Michels JJ, Duigou F, Marnay J, Denoux Y, Delozier T and Chasle J: Flow cytometry in primary breast carcinomas: prognostic impact of multiploidy and hypoploidy. Cytometry B Clin Cytometry 55: 37-45, 2003.

10. Michels JJ, Marnay J, Plancoulaine B and Chasle J: Flow cytometry in primary breast carcinomas: prognostic impact of S-phase fraction according to different analysis patterns. Cytometry B Clin Cytometry 59: 32-39, 2004.

11. Kute TE, Russell GB, Zbieranski N, et al: Prognostic markers in node-negative breast cancer: a prospective study. Cytometry B Clin Cytometry 59: 24-31, 2004.

12. Moureau-Zabotto L, Bouchet C, Cesari D, et al: Combined flow cytometry determination of S-phase fraction and DNA ploidy is an independent prognostic factor in node-negative invasive breast carcinoma: analysis of a series of 271 patients with stage I and II breast cancer. Breast Cancer Res Treat 91: 61-71, 2005.

13. Pinto AE, Andre S and Soares J: Short-term significance of DNA ploidy and cell proliferation in breast carcinoma: a multivariate analysis of prognostic markers in a series of 308 patients. J Clin Pathol 52: 604-611, 1999.

14. Hedley DW, Clark GM, Cornelisse CJ, Killander D, Kute T and Merkel D: DNA Cytometry Consensus Conference. Consensus review of the clinical utility of DNA cytometry in carcinoma of the breast. Breast Cancer Res Treat 28: 55-59, 1993.

15. Baldetorp B, Bendahl PO, Ferno M and Stal O: Improved DNA flow cytometric, DNA ploidy, and S-phase reproducibility between 15 laboratories in analysis of breast cancer using generalized guidelines. Cytometry A 56: 1-7, 2003.

16. Schvimer M, Lash RH and Katzin WE: Intratumoral heterogeneity of DNA ploidy in breast carcinomas: a flow cytometric assessment of sampling techniques. Cytometry 22: 292-296, 1995.

17. Duigou F, Herlin P, Marnay J and Michels JJ: Variation of flow cytometric DNA measurement in 1,485 primary breast carcinomas according to guidelines for DNA histogram interpretation. Cytometry 42: 35-42, 2000.
18. Frierson HF Jr, Wolber RA, Berean KW, Franquemont DW, Berean KW, Wolber RA and Kiss R: Interobserver reproducibility of the Nottingham modification of the Bloom and Richardson histologic grading scheme for infiltrating ductal carcinoma. Am J Clin Pathol 103: 195-198, 1995.

19. Chavez-Uribe EM, Vinuela JE, Cameselle-Teijeiro J, Forteza J, Puñal JA, Otero JL and Puente-Domínguez JL: DNA ploidy and cytonuclear area of peritumoral and paratumoral samples of mastectomy specimens: a useful prognostic marker? Eur J Surg 168: 37-41, 2002.

20. Chassevent A, Jourdan ML, Romain S, et al: S-phase fraction and DNA ploidy in 633 T1T2 breast cancers: a standardized flow cytometric study. Clin Cancer Res 7: 909-917, 2001.

21. Jourdan ML, Ferrero-Pous M, Spyratos F, Romain S, Martin PM and Chassevent A: Flow cytometric S-phase fraction measurement in breast carcinoma: Influence of software and histogram resolution. Cytometry 48: 66-70, 2002.

22. Wenger CR and Clark GM: S-phase fraction and breast cancer - a decade of experience. Breast Cancer Res Treat 51: 255-265, 1998.

23. Fernö M, Baldetorp B, Borg Å, Olsson H, Sigurdsson H and Killander D: Flow cytometric DNA index and S-phase fraction in breast cancer in relation to other prognostic variables and to clinical outcome. Acta Oncol 31: 157-165, 1992.

24. Bracko M, Us-Krasovec M, Cufer T, Lamovec J, Zidar A and Goehde W: Prognostic significance of DNA ploidy determined by high-resolution flow cytometry in breast carcinoma. Anal Quant Cytol Histol 23: 56-66, 2001.

25. Lawry J, Rogers K, Duncan JL and Potter CW: The identification of informative parameters in the flow cytometric analysis of breast carcinoma. Eur J Cancer 29A: 719-723, 1993.

26. Stal O, Carstensen J, Hatschek T and Nordenskjold B: Significance of S-phase fraction and hormone receptor content in the management of young breast cancer patients. Br J Cancer 66: 706-711, 1992.

27. Bagwell CB, Clark GM, Spyratos F, et al: Optimizing flow cytometric DNA ploidy and S-phase fraction as independent prognostic markers for node-negative breast cancer specimens. Cytometry 46: 121-135, 2001.

28. Stal O, Wingren S, Carstensen J, Rutqvist LE, Skoog L and Klintenberg C: Prognostic value of DNA ploidy and S-phase fraction in relation to estrogen receptor content and clinicopathological variables in primary breast cancer. Eur J Cancer Clin Oncol 25: 301-309, 1989.

29. Wenger CR, Beardslee S, Owens MA, et al: DNA ploidy, S-phase, and steroid receptors in more than 127,000 breast cancer patients. Breast Cancer Res Treat 28: 9-20, 1993.

30. Tanner MM, Karhu RA, Nupponen NN, et al: Genetic aberrations in hypodiploid breast cancer. Frequent loss of chromosome 4 and amplification of cyclin D1 oncogene. Am J Pathol 153: 191-199, 1998.

31. Rennstam K, Ahlsted-Soini M, Baldetorp B, et al: Patterns of chromosomal imbalances defines subgroups of breast cancer with distinct clinical features and prognosis. A study of 305 tumors by comparative genomic hybridization. Cancer Res 63: 8861-8868, 2003. 